\title{
Anti-PD1 Monoclonal Antibody
}

National Cancer Institute

\section{Source}

National Cancer Institute. Anti-PD1 Monoclonal Antibody. NCI Thesaurus. Code

C128037.

A monoclonal antibody directed ag ainst programmed cell death protein 1 (PD-1; PD1; CD279). 